EREM 73/2

Journal of Environmental Research, Engineering and Management Vol. 73 / No. 2 / 2017 pp. $62-73$ DOl 10.5755/j01.erem.73.2.18193 (c) Kaunas University of Technology

\section{Model-based Design of a Pilot Circulating Bed Membrane Bioreactor for Sewage Treatment}

Received 2017/05

Accepted after revision 2017/07

\title{
Model-based Design of a Pilot Circulating Bed Membrane Bioreactor for Sewage Treatment
}

\author{
Abdul-Fattah Mohamed Ali, Zainab Ziad Ismail \\ Department of Environmental Engineering, Baghdad University, Baghdad, Iraq
}

Corresponding author: zismail9@gmail.com

Zainab Z. Ismail, Baghdad University, Department of Environmental Engineering, Baghdad, Iraq

Population growth in developing countries leads to overloading existing sewage treatment plants. Additionally, suburban residential complexes are sometimes constructed and inhabited before their sewage treatment facilities are ready for various reasons. Therefore, there is a need for locally developed package units, which should be robust, modular, and require minimum maintenance. The following article describes the conceptual design of a hybrid bioreactor of such a unit intended to treat $120 \mathrm{~m}^{3}$ of sewage per day. The design makes use of published literature in this regard over the last three decades. The proposed bioreactor consists of an upstream circulating bed compartment (CBC) with plastic biofilm carriers and a downstream microfiltration membrane compartment (MMC). Each of these two compartments has a nominal effective volume of $29 \mathrm{~m}^{3}$. The $\mathrm{CBC}$ is mainly anoxic whilst the MMC is aerobic (oxic) making the reactor an A/0 arrangement. Following implementation, an initial experimental phase is envisaged to tune the reactor with respect to functionality and maximisation of nitrogen removal. Details of this tuning phase are also given in the article.

Keywords: sewage treatment, hybrid bioreactor, circulating bed, submerged membrane, biomass carriers.

\section{Introduction}

Developing countries, in general, face a big challenge of treating domestic sewage from an increasing number of decentralised residential complexes and overloaded existing treatment plants due to population growth. Suitable sewage treatment by robust package units would solve an existing environmental 
problem as well as provide safe irrigation water for landscape areas and/or crops. Circulating bed biofilm reactors as well as membrane bioreactors and hybrid membrane bioreactors were utilised in the development of the conceptual design of the proposed hybrid bioreactor.

\section{Circulating bed biofilm reactors}

Circulating bed biofilm reactors have been used for wastewater treatment for nearly two decades (Heijnen et al., 1997, Lazarova et al., 1997). They are based on three-phase internal-loop airlift reactors (inter alia: Lu et al., 1995, Hwang et al., 1997). An airlift reactor is made up of a liquid (and solid) pool, which is divided into two vertical sections connected at the top and bottom. One of the two sections is aerated (the riser) resulting in liquid circulation due to gas holdup and density differences between the riser and the other section (the downcomer). The solid phase, which is the biofilm carrier, may be heavier-than-water particles like 0.09-0.3-mm basalt (Circox ${ }^{R}$ reactor) (Frijters et al., 1997) or lighter-than-water particles like 0.5-4$\mathrm{mm}$ polyethylene granules (Lazarova et al., 1997). The solid phase filling ratio (FR) $\left(\mathrm{m}^{3}\right.$ solid bulk per $\mathrm{m}^{3}$ reactor empty volume) is $5-15 \%$ for basalt and $10-40 \%$ for polyethylene granules. It is noteworthy that larger plastic biofilm carriers which are used in moving bed biofilm reactors (e.g., AnoxKaldnes ${ }^{\mathrm{R}} \mathrm{K} 1$ polyethylene carriers (Rusten et al., 2006) and polyurethane foam cubes 1-2 cm in size (Chu \& Wang, 2011, Quan et al., 2012)) are not used in pilot/industrial-scale circulating bed reactors. They are, however, used in few lab-scale circulating bed reactors (1-cm polyurethane cubes, 20\% FR (Yang et al., 2006); Hacketten carrier and cylindrical carrier similar to K1, 50\% FR (Zhang et al., 2014); oblique cylinder $60 \%$ inclination angle $2 \mathrm{~cm} \varphi \times 2.5 \mathrm{~cm}$ similar to K1, 50\% FR (Zhang et al., 2014)).

The liquid circulation velocity is the most important parameter in the design and operation of airlift biofilm reactors. It depends on a number of factors, foremost of which is the sparged air-rate in the riser, which is usually expressed as superficial air velocity $U_{s g}$ leading to a certain gas holdup $\epsilon_{\mathrm{G}}$ in the liquid and expressed as $\epsilon_{G}=a\left(U_{s g}\right)^{b}$, where $a$ and $b$ are constants whose values are regime and system specific. For air-water system and bubble regime $\left(\mathrm{U}_{\mathrm{sg}}<0.05 \mathrm{~m} / \mathrm{s}\right)$ (Chisti et al., 1988):

$$
\epsilon_{\mathrm{G}}=2.47\left(\mathrm{U}_{\mathrm{sg}}\right)^{0.97}
$$

and the superficial liquid velocity $U_{L}$ for internal-loop airlift reactors with the air-water system (Chisti et al., 1988):

$$
\begin{aligned}
& \mathrm{U}_{\mathrm{L}}=\left[2 \mathrm{gh} \mathrm{h}_{\mathrm{D}}\left(\epsilon_{\mathrm{r}}-\epsilon_{\mathrm{d}}\right) /\left(\mathrm{K}_{\mathrm{B}}\left(\mathrm{A}_{\mathrm{r}} / \mathrm{A}_{\mathrm{d}}\right)^{2}\right.\right. \\
& \left.\left(1 /\left(1-\epsilon_{\mathrm{d}}\right)^{2}\right)\right]^{0.5}
\end{aligned}
$$

where

$g$ is the acceleration due to gravity $\left(m / s^{2}\right), h_{D}$ is the dispersion height $(m), \epsilon_{r}$ and $\epsilon_{d}$ are the gas holdup in the riser and the downcomer, respectively $(-), K_{B}$ is the bottom loss coefficient (downcomer to riser) (-), ( $A_{r} /$ $A_{d}$ ) is the ratio of riser to downcomer cross-sectional areas.

Further,

$$
\mathrm{K}_{\mathrm{B}}=11.402\left(\mathrm{~A}_{\mathrm{d}} / \mathrm{A}_{\mathrm{b}}\right)^{0.789}
$$

where

$A_{b}$ is the free area for liquid flow between the downcomer and the riser $\left(\mathrm{m}^{2}\right)$.

If $\epsilon_{d}=0$ and $A_{r} / A_{d}=1$, Eq. (2) reduces to

$$
\mathrm{U}_{\mathrm{L}}=\left(2 \mathrm{~g} \mathrm{~h} \epsilon_{\mathrm{r}} / \mathrm{K}_{\mathrm{B}}\right)^{0.5}
$$

The linear liquid velocity is simply:

$$
\mathrm{V}_{\mathrm{L}}=\mathrm{U}_{\mathrm{L}} /\left(1-\epsilon_{\mathrm{r}}\right)
$$

According to Heijnen et al. (1997), for $0.006<\mathrm{U}_{\mathrm{sg}}<$ $0.06 \mathrm{~m} / \mathrm{s}$, the riser can be approximated to behave as a bubble column, for which

$$
\epsilon_{\mathrm{G}}=0.6\left(\mathrm{U}_{\mathrm{sg}}\right)^{0.7}
$$


for aqueous systems (Heijnen \& Van't Riet, 1984). They pointed out that Eq. (6) gives a reasonable prediction of the riser's gas holdup without gas in the downcomer $\left(\epsilon_{d}=0\right)$ (Van der Lans, 1985). Hence, the linear liquid velocity for three-phase airlift reactor becomes:

$$
\begin{aligned}
& \mathrm{V}_{\mathrm{L}}=\left(4 \mathrm{~g} \mathrm{~h} \mathrm{D} / \mathrm{K}_{\mathrm{B}}\right)^{1 / 3}\left\{0.3 \mathrm{~V}_{\mathrm{L}}\left(\mathrm{U}_{\mathrm{sg}} / \mathrm{m}\right)^{0.7}-\right. \\
& \left.\epsilon_{\mathrm{S}} \mathrm{V}_{\mathrm{sp}}\left(\mathrm{Q}_{\mathrm{s}} / \mathrm{Q}_{\mathrm{L}}-1\right)\right\}^{1 / 3}
\end{aligned}
$$

where

$m=A_{r} / A_{t}$ is the ratio of the riser cross-sectional area to the reactor total cross-sectional area, $\epsilon_{\mathrm{s}}$ is the solid phase holdup, and $v_{\mathrm{sp}}$ is the particles swarm velocity.

If $Q_{s} \approx Q_{L}$, Eq. (7) reduces to

$$
\mathrm{V}_{\mathrm{L}}=\left(1.2 \mathrm{~g} \mathrm{~h} / \mathrm{K}_{\mathrm{B}}\right)^{1.2}\left(\mathrm{U}_{\mathrm{sg}} / \mathrm{m}\right)^{0.35}
$$

Eqs. (4), (5) and (8) were used to estimate $V_{L}$ in the $\mathrm{CBC}$ of the proposed bioreactor.

The presence of a solid phase alters the hydrodynamics of airlift reactors. This is so even with low-density solids where the solid-liquid system may be considered as pseudo-homogeneous. Karamaenev et al. (1992) found that with the presence of $3-\mathrm{mm}$ soft polyurethane particles, $\epsilon_{G}$ decreased significantly with increasing $\epsilon_{\mathrm{s}}$ and that $\epsilon_{\mathrm{g}}$ varied with $\left(\mathrm{U}_{\mathrm{sg}}\right)^{1.2}$. Miyahara and Miyahara \& Kawate (1993) showed that $\epsilon_{\mathrm{G}}$ decreased significantly when $\epsilon_{\mathrm{s}}>0.2$ for low density particles. Lu et al. (1995) found that $\epsilon_{\mathrm{G}}$ decreased with an increasing particle size (calcium alginate beads, $\varrho_{s}=$ $1.03 \mathrm{~kg} / \mathrm{L}$ ). However, contrary to the aforementioned findings, Lazarova et al. (1997) reported that the introduction of $10-40 \%(\mathrm{v} / \mathrm{v})$ polyethylene granules improved $\epsilon_{G}$. They pointed out this contradiction by stating that the effect of solid particles on $\epsilon_{G}$ could be negative, neutral, or positive when comparing their work with previous studies.

It is clear from the foregoing that it is difficult to predict a priori (i.e., at the design stage) $\epsilon_{G}$ and $V_{L}$ for a particular system with a specific regime. It is, nevertheless, useful to assume the air-water system with a commensurate regime to obtain $\epsilon_{G}$ and $V_{L}$ from reasonably reliable predictive models available in the literature. Generally, such an approach will over-predict $V_{L}$ values.

The absence of air bubbles in the downcomer makes it anoxic. This is achieved by a low flow rate in the riser $\left(U_{s g}<0.05 \mathrm{~m} / \mathrm{s}\right)$ and a riser-downcomer headspace, which facilitates the disengagement of air bubbles. In this case, $V_{L}$ in the downcomer is lower than the bubble terminal velocity. This condition renders an airlift reactor an alternating anoxic-aerobic system, creating multi-environments which support diversified microbial communities (Andersen et al., 2013, Colares \& Melo, 2013, Duan et al., 2013), enhancing COD as well as nutrient removal (Hocaoglu et al., 2011).

For nitrogen removal, complete nitrification $\left(\mathrm{NH}_{4}^{+}+\right.$ $\mathrm{AOB} \rightarrow \mathrm{NO}_{2}^{-}+\mathrm{NOB} \rightarrow \mathrm{NO}_{3}^{-}$) is neither necessary nor energy-efficient. The formation of nitrite by ammonia oxidising bacteria (AOB) is of significance and should be maximised, whilst the formation of nitrate by nitrite oxidising bacteria (NOB) should be minimised. This approach (Picioreanu et al., 1996) will:

save energy due to lower oxygen requirement in the aerobic zone;

2 require a lesser amount of electron donor (COD) in the anoxic zone;

3 make the denitrification rate faster because the nitrite denitrification rate is 1.5 to 2 times higher than that of nitrate.

Practically, $\mathrm{NH}_{4}^{+}$conversion to $50 \%$ maximum $\mathrm{NO}_{2}^{-}$ and $50 \%$ minimum $\mathrm{NO}_{3}{ }^{-}$was achieved with controlled oxygen concentration of $1-2 \mathrm{mg} / \mathrm{L}$ in the aerobic zone (Garrido et al., 1997). This dissolved oxygen level is significantly lower than that which is usually used to ensure full ammonia nitrification (up to $7.5 \mathrm{mg} / \mathrm{L}$ ).

\section{Membrane bioreactors and hybrid membrane bioreactors}

Submerged membrane bioreactors represent a well-established proven wastewater treatment technology. Numerous research works have been published over the last two decades about every aspect of this topic. Among the most successful submerged membrane commercial units are the ultra-filtration 
ZeeWeed ${ }^{R}$ hollow-fiber range with nominal molecular weight cut-off of 200 kDalton (Zenon Environmental Inc., Burlington, Canada) and the microfiltration Kubota flat-sheet range with a nominal pore size of 0.4 um (Kubota Corp., Japan) (Tchobanoglous et al., 2003). Scaled down versions of these units were used in some eminent researches (inter alia: Cote et al., 1997, Chua et al., 2004, Sofia et al., 2004).

The concept of a hybrid biofilm membrane bioreactor was introduced in 2006 by Leiknes et al. (2006) in the hope of reducing membrane fouling by high biomass concentrations. It consisted of an upstream moving-bed biofilm reactor and a downstream submerged membrane unit (MBMBR). It was claimed that this arrangement could be designed to accept high particulate as well as soluble organic load (Leiknes \& Ødegaard, 2007). Succeeding research works revealed that the microbial spectrum in a hybrid biofilm membrane bioreactor was significantly different from that in a conventional membrane bioreactor (MBR) (Yang et al., 2009). Filamentous bacteria, protozoa like Ciliates, Vorticella, Amoebae, as well as metazoans including Rotifers and Nematodes were far more abundant in the hybrid reactor than the conventional membrane reactor. Yang et al. (2009) concluded that the microbial multifariousness was considerably richer in the hybrid MBMBR than that in a conventional MBR. The overgrowth of filamentous bacteria inhabiting the biofilm and sludge suspension in the hybrid MBMBR resulted in a thick and dense cake layer on the membrane surface. This led to more severe membrane fouling in the hybrid reactor as compared with the conventional one. Zhu et al. (2015) confirmed that filamentous bacteria were important components for biofilm formation and development, becoming dominant in a mature biofilm. They include Sphaerotilus, Haliscomenobacter, and Actinobacteria. However, other filamentous bacterial species are known to cause foaming and bulking, like Microthrix parvicella and Pseudomonas aeruginosa (Neis et al., 2012). Therefore, the overgrowth of filamentous bacteria, in general, needs to be controlled to safeguard the bioprocess and the filtration membrane. Additionally, the microbial community composition of the biofilm was demonstrated to be related to the FR of carriers, e.g., 30\% FR showed higher diversity of nitrifying bacteria, leading to higher ratios of nitrogen removal as compared with 10\% FR (Calderon et al., 2012). No significant differences of the microbial composition were observed in the same study due to the type of carrier used.

In the development of the proposed hybrid bioreactor conceptual design in this study, both an anoxic circulating bed part and an aerobic submerged membrane part were connected in series in an $\mathrm{A} / \mathrm{O}$ arrangement to utilise both attached and suspended biomass for organic carbon and nitrogen removal. No external mixing provision shall be required for the anoxic zone of the circulating bed part. The functionality of the proposed bioreactor rests on the described design as well as the given initial experimental tuning phase.

\section{Conceptual design and methodology}

\section{Architecture of the proposed pilot circulating bed-membrane hybrid bioreactor}

The proposed hybrid bioreactor is in the form of a rectangular container with overall dimensions of $5 \times 4.3 \times 3 \mathrm{~m}(\mathrm{~L} \times \mathrm{W} \times \mathrm{H})$. This structure is to be divided into two equal compartments each with a nominal effective volume of $29 \mathrm{~m}^{3}$. The upstream circulating bed compartment $(\mathrm{CBC})$ shall in turn be divided into two equal sections with a 2 -m-long vertical baffle to be positioned with its upper edge $0.4 \mathrm{~m}$ below the liquid level and its lower edge $0.3 \mathrm{~m}$ above the reactor's bottom. One of the two sections shall be equipped with a coarse air sparger in the form of a perforated pipe-network, making it the riser. The air sparger is to be positioned initially $0.5 \mathrm{~m}$ above the reactor's bottom ( $0.2 \mathrm{~m}$ above the baffle's lower edge). This arrangement will aerate only $2.2 \mathrm{~m}$ of the total circulating bed cycle path of $5.4 \mathrm{~m}$ (40\%). The riser-downcomer headspace shall be $2.5 \times 4.3 \mathrm{~m}$, which is conducive to air bubble disengagement. Raw sewage flows into the reactor at the top of the downcomer and outflows the CBC to the adjacent downstream submerged membrane compartment (SMC) via a suitable mesh at the top of the riser.

The SMC shall house four flat-sheet ES-100 Kubota microfiltration single-deck units. Each unit consists of a membrane case on top of a diffuser case. The 
membrane case contains 100 flat-sheet cartridges, each with $0.8 \mathrm{~m}^{2}$ microfiltration area (two sides). Therefore, the total filtration area of the submerged membrane compartment shall be $320 \mathrm{~m}^{2}$. The diffuser case houses at its bottom an air pipe, running the length of the unit, with ten lateral $10-\mathrm{mm}$ branches. Each lateral branch contains five 6-mm holes. Hence, the diffuser is a coarse air-bubble one providing the necessary air to create the up-flow through the membrane case (to maintain the functionality of the membranes) as well as the dissolved oxygen required for the aerobic condition in this compartment. The positioning of the aforementioned four ES-100 units and the overall dimensions of the SMC are according to the minimum dimensions stipulated by Kubota Manual (Kubota Corp.). Provision shall also be made to return mixed liquor from the SMC to the top of the downcomer section of the $\mathrm{CBC}$ at a maximum flow rate of three times the reactor's inflow rate. A side stream of this return flow will be sonicated to control the overgrowth of filamentous bacteria. Additionally mixed liquor shall be wasted from both compartments to control SRT at a desired value. Figure 1 shows a schematic top-view of the proposed reactor $(A)$ and a schematic side-view of it (B).
Fig. 1

Schematic diagram of the proposed bioreactor; (A) Topview, (B) Side-view

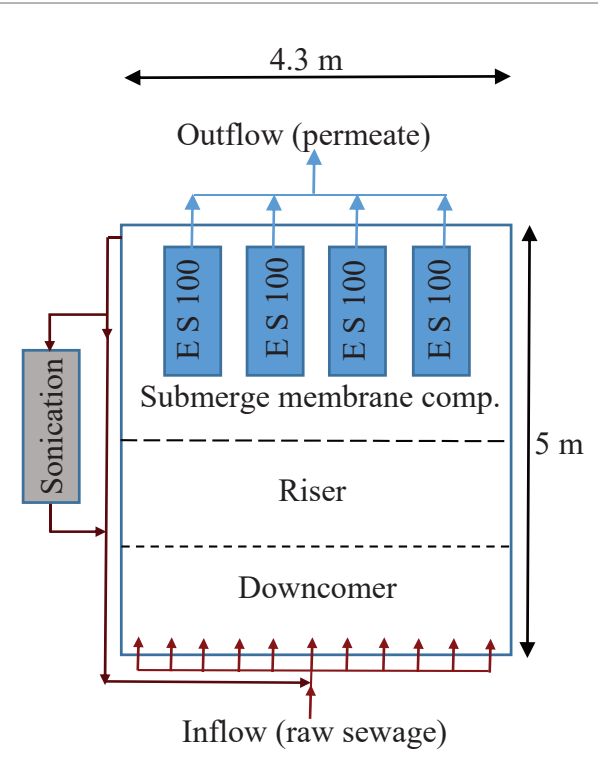

a

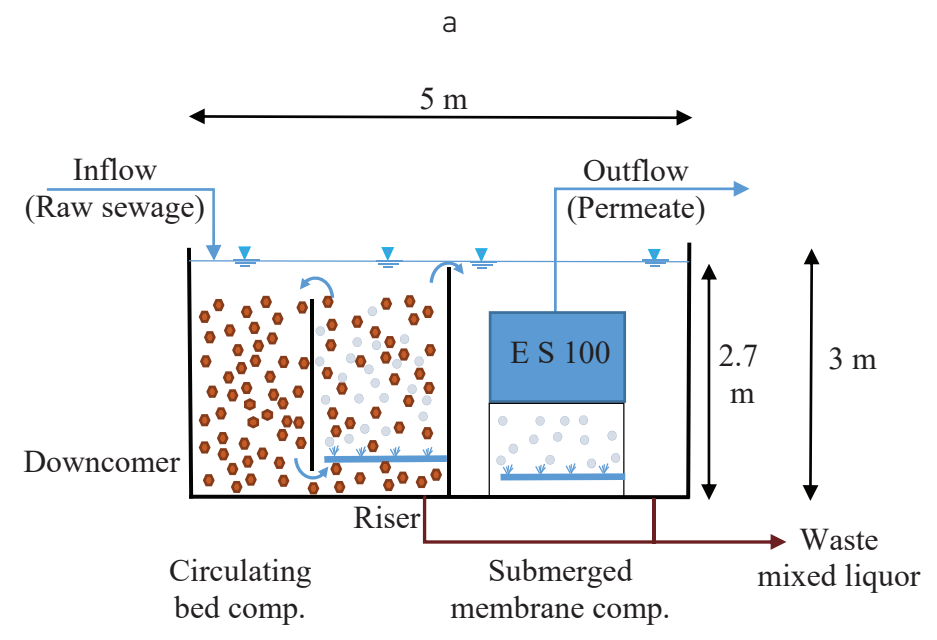

b 


\section{Estimation of $V_{L}$ in the CBC of the proposed bioreactor}

Following the specification of the architectural particulars of the proposed bioreactor, the important parameter $V_{L}$ can now be estimated by using the two models represented by Eqs. (4), (5), and (8). Initially, $K_{B}$ value needed in both models must be determined. Applying Eq. (3) and noting that $A_{d}=1.25 \times 4.3 \mathrm{~m}$ and $A_{b}=0.3 \times 4.3 \mathrm{~m}, K_{B}=35$. Also, for $\epsilon_{r}$ in Eq. (4), the value of $\epsilon_{G}$ from Eq. (1) will be used, $m=0.5$ in Eq. (8), and $h_{D}=2.2 \mathrm{~m}$ assuming no significant difference between the dispersion height and the liquid height above the air sparger in the riser due to the very low air flow rate $\left(\mathrm{U}_{\mathrm{sg}}<0.05 \mathrm{~m} / \mathrm{s}\right.$, bubble regime). The values shown in Table 1 are consequently obtained.

\section{Table 1}

$V_{\llcorner}$values using the models described by Eqs. (4), (5) and (8)

\begin{tabular}{c|c|c}
\hline $\mathrm{U}_{\mathrm{sg}}(\mathrm{m} / \mathrm{s})$ & $\mathrm{V}_{\mathrm{L}}(\mathrm{m} / \mathrm{s})$ Eqs. (4) and $(5)$ & $\mathrm{V}_{\mathrm{L}}(\mathrm{m} / \mathrm{s})$ Eq. (8) \\
\hline 1 & 2 & 3 \\
\hline 0.01 & 0.192 & 0.219 \\
\hline 0.02 & 0.277 & 0.279 \\
\hline 0.03 & 0.347 & 0.321 \\
\hline 0.04 & 0.411 & 0.355 \\
\hline
\end{tabular}

The similarity of $V_{L}$ values from the two models was expected because both apply to the same regime and similar systems. However, Eq. (8) gives lower $V_{L}$ values as $U_{\text {sg }}$ increases since it is relevant to 3-phase aqueous systems whereas Eqs. (4) and (5) are relevant to an air-water system. The actual $V_{L}$ values in the proposed bioreactor are expected to be lower than the values given in Table 1 primarily due to the non-Newtonian (pseudoplastic) nature of the mixed liquor with an apparent viscosity significantly higher than the viscosity of water or aqueous solutions (Hasar et al., 2004, Tang et al., 2015).

\section{Type and filling ratio (FR) of biomass carriers in the $C B C$ of the proposed bioreactor}

Since the advent of moving bed biofilm reactors (MBBR), many biomass carriers of various designs and materials have been developed and used in lab/ industrial-scale bioreactors. Foremost of these carriers are the previously mentioned AnoxKladnes ${ }^{R} \mathrm{~K} 1$ and polyurethane foam cubes $1-2 \mathrm{~cm}$ in size. The $\mathrm{K} 1$ carrier is made of high-density polyethylene with actual and bulk densities of $0.95 \mathrm{~g} / \mathrm{cm}^{3}$ and $150 \mathrm{~kg} / \mathrm{m}^{3}$, respectively. It has a cylindrical shape with a nominal diameter and a length of $9 \mathrm{~mm}$ and $7 \mathrm{~mm}$, respectively. It contains a cross inside the cylinder and longitudinal fins around its outer perimeter (Rusten et al. 2006). For lab-scale MBBRs, the maximum K1 FR used is $67-70 \%(\mathrm{v} / \mathrm{v})$, and for industrial-scale MBBRs, it is less than $50 \%$ (e.g., $46 \%$ in $130 \mathrm{~m}^{3}$ MBBR) (Pal et al., 2013). Each percentage point K1 FR (v/v) contributes a $5 \mathrm{~m}^{2}$ effective surface area for microbial film growth per $\mathrm{m}^{3}$ of reactor volume (e.g., for $\mathrm{FR}=60 \%$, the effective area will be $300 \mathrm{~m}^{2} / \mathrm{m}^{3}$ ). Polyurethane foam cubes (PFC) have a much lower bulk density of $25-30 \mathrm{~kg} / \mathrm{m}^{3}$ and a very high porosity of $90 \%$ or more with an average pore size of $1.0-1.5 \mathrm{~mm}$. Its specific surface area is $900-1120 \mathrm{~m}^{2} / \mathrm{m}^{3}$. Therefore, its FR is considerably less than that of the $\mathrm{K} 1$ carrier; a maximum of 40\% [7-9]. Additionally, PFC can be modified in two ways: by coating it with activated carbon to increase its specific surface area to $35,000 \mathrm{~m}^{2} / \mathrm{m}^{3}$ (1.3 cm cubes) (Lee et al., 2006) making it hydrophilic-cationic to achieve faster water immersion and increase its affinity for microbial film attachment (Chu et al., 2014).

The planned experimental tuning phase of the proposed bioreactor will include testing K1 and PFC carriers in the CBC. For each carrier type, it is envisaged to start the test with $5 \% \mathrm{FR}$, following careful cultivation and maturing of the microbial biofilm in a batch-mode with real domestic sewage over a period of 45 days. This period would ensure the formation and development of the microbial biofilm in its four stages; namely, initial attachment, accumulation, sloughing and updating, and finally maturation (Zhu et al., 2015, Di Trapani et al., 2014). The 5\% FR shall then be increased stepwise to $10 \%, 15 \%$, etc. whilst maintaining the bubble regime in the riser $\left(U_{s g}<0.05 \mathrm{~m} / \mathrm{s}\right)$ throughout. The objective is to obtain the maximum practicable FR while maintaining functional liquid circulation in order to minimise the thickness of the microbial biofilm on the carrier [8]. A biofilm thickness of 100-200 $\mu \mathrm{m}$ 
is generally considered to be acceptable for oxygen, organic matter, and nutrient diffusion (Nogueira et al., 1998).

\section{Details of the riser's air sparger}

The main air pipe shall be of 4-inch size $(100 \mathrm{~mm})$ to be placed horizontally on top of the bioreactor running along the $4.3-\mathrm{m}$ dimension. This pipe shall have five 1 -inch size $(25 \mathrm{~mm})$ branches going vertically down along the riser's side to the specified location $(0.5 \mathrm{~m}$ above the reactor's bottom) where the branches turn horizontal over the riser's $1.25-\mathrm{m}$ dimension. Centre-line distance between any two neighbouring branches shall be about $0.7 \mathrm{~m}$ and each branch shall have in its horizontal run six holes 6-mm in diameter pointing downward with about $0.18 \mathrm{~m}$ between any two neighbouring holes. All pipes shall be of plastic material and each branch in its vertical run shall be provided with couplings and short pipe sections to facilitate changing the location of the sparger with respect to the reactor's bottom in order to vary the dispersion height $h_{D}$ as required to obtain the desirable liquid circulation during the experimental tuning phase. This arrangement will allow the variation of the ratio of oxic/anoxic zones in the CBC.

\section{Basis for specifying four ES-100 microfiltration units in the SMC}

There are two main aspects to the choice of four ES100 microfiltration units for the SMC of the proposed bioreactor. The first aspect is related to the previously mentioned $320 \mathrm{~m}^{2}$ filtration area which in turn determines the permeate flux value at $15.625 \mathrm{~L} / \mathrm{h}$. $\left.\mathrm{m}^{2}\right)(\mathrm{LMH})$ for $120 \mathrm{~m}^{3} / \mathrm{d}$ of sewage flow. It is well known that the permeate flux value is the most significant parameter affecting the membrane fouling rate. The concept of critical flux, introduced by Field et al. (1995), is a widely used standard in this regard. It is defined as the highest flux for which transmembrane pressure (TMP) remains stable and is dependent on the mixed liquor characteristics, the membrane material, as well as the system's hydrodynamics. A permeate flux value below the critical flux (subcritical flux) limits membrane fouling and extends operational periods. This extension is obviously a function of the ratio of actual to critical fluxes. It is also obvious that a lower permeate flux entails a high filtration area (higher investment and fixed cost); ultimately, a compromise must be struck between these two conflicting parameters.

Table 2 lists values of permeate flux through Kubota microfiltration membranes along with their relevant details and references.

It should be noted that the permeate flux values of Table 2 are all in conjunction with evenly distributed air diffusion within the range 0.75-1.125 $\mathrm{m}^{3}$ air per hour per $\mathrm{m}^{2}$ filtration area according to Kubota's specifications (Kubot Corp., 2002), in order to scour the membranes. This air scouring would make the biofilm covering the membrane's surface only a few micrometres thick, with a TMP of about $5 \mathrm{kPa}$ during normal operation rising gradually to $14 \mathrm{kPa}$ prior to cleaning (3 to 6 months) (Trivedi, 2004).

\section{Table 2}

Values of permeate flux through Kubota microfiltration membranes

\begin{tabular}{c|l|c}
\hline Flux (LMH) & \multicolumn{1}{|c|}{ Notes } & Reference \\
\hline 1 & \multicolumn{1}{|c}{2} & 3 \\
\hline 16.9 & $\begin{array}{l}\mid c \\
\text { Lab-scale (9 liter), raw domes- } \\
\text { tic sewage }\end{array}$ & {$[27]$} \\
\hline 15.625 & $\begin{array}{l}30 \mathrm{~m}^{3} / \mathrm{d} \text { kitchen wastewater } \\
(\text { BOD=300 mg/L), Kubota } \\
\text { Hanshin Office, Japan }\end{array}$ & {$[43]$} \\
\hline 25 & $\begin{array}{l}\text { Enviroquip Inc. (USA), re- } \\
\text { commended }\end{array}$ & {$[44]$} \\
\hline 28 & $\begin{array}{l}\text { Hirakata, Japan, sewage of } \\
\text { apartment complex }\end{array}$ & {$[44]$} \\
\hline 21 & $\begin{array}{l}\text { Pilot-scale, primary effluent of } \\
\text { wastewater treatment plant }\end{array}$ & {$[45]$} \\
\hline & $\begin{array}{l}\left.\text { Pilot-scale (1.2 m }{ }^{3}\right) \text { MBR, raw } \\
\text { domestic sewage }\end{array}$ & {$[46]$} \\
\hline
\end{tabular}

A rough estimate of the critical flux in the submerged membrane compartment of the proposed bioreactor can be obtained from the empirical model of Verrecht et al. (2009), based on the data from pilot-scale units employing flat-sheet membranes with three-monthly chemical cleaning: 


$$
\mathrm{J}_{\text {crit }, 20}=391.71 \mathrm{U}+11.783 \quad\left(\mathrm{R}^{2}=0.8987\right)
$$

where

$\mathrm{J}_{\text {crit,20 }}$ is the critical flux at 20 deg.C in LMH and $U$ is the in-module air up-flow velocity in $\mathrm{m} / \mathrm{s}$.

Applying this model to the ES-100 unit with an air diffusion rate within the previously mentioned range of 0.75-1.125 $\mathrm{m}^{3}$ air per hour per $\mathrm{m}^{2}$ filtration area results in $22 \leq \mathrm{J}_{\text {crit,20 }} \leq 27 \mathrm{LMH}$. These values are most likely an underestimate; nevertheless, the specified permeate flux value of $15.625 \mathrm{LMH}$, which is the minimum in Table 2, should be well below the actual critical flux value of the ES-100 unit. It is also clear from Eq. (9) that when one ES-100 unit is taken out of service for maintenance, the rate of air diffusion should be maximised to the other three units to keep the permeate flux well below the critical value.

The second aspect for the choice of four ES-100 units is related to operation and maintenance. Operation may include a relax-mode; 9- min "on", 1-min "off" cycles (Trussell et al., 2006), cleaning-in-place or complete removal of one ES-100 unit for maintenance. This would increase the flux to a value of $20.8 \mathrm{LMH}$ for a limited period of time. Operation and maintenance are always problematic in developing countries; they need to be considered carefully. Breakdown maintenance is the norm whereas scheduled preventive maintenance is the exception. A case in point is adopting pumped permeate flow for the proposed bioreactor instead of gravity flow in spite of the latter's simplicity. Operators can simply increase the vacuum (or TMP) across the membrane to maintain the specified permeate flow until a problem is solved.

\section{Operating parameters of the proposed bioreactor}

\section{Hydraulic retention time (HRT)}

The overall average HRT of the proposed bioreactor is about 11 hours, split in the middle between the circulating bed and the submerged membrane compartments with 5.5 hours each. The initial set-up of the bioreactor shall have $30 \%$ of its HRT as anoxic ( 3.3 hours within the $\mathrm{CBC}$ ) and $70 \%$ as oxic (7.7 hours, 2.2 hours within the $\mathrm{CBC}$ and 5.5 hours within the $\mathrm{SMC}$ ). To appreciate the specified HRT value and its breakdown, a short review of HRT values in circulating bed and submerged membrane bioreactors is in order.

The previously mentioned Circox ${ }^{R}$ airlift bioreactor with an integrated denitrification section (Frijters et al., 1997) had an HRT of 2 hours when treating municipal wastewater (67\% domestic sewage and 33\% industrial wastewater). The anoxic denitrification section volume constituted $34 \%$ of the reactor's total volume; however, its retention time was only 8 minutes. The circulating bed bioreactor of Lazarove et al. (1997) had a $0.6 \leq$ HRT $\leq 4$ hours when treating pre-settled municipal wastewater. It had no anoxic denitrification section, so for this purpose it was coupled with a floating bed denitrification reactor.

HRT values of aerobic submerged membrane bioreactors treating municipal wastewater extend over a wide range, e.g., 1.5 hours (Trussell et al., 2005) to 16 hours (Yoon et al., 2004). Generally, low values of HRT are employed for COD removal only (high-loading rates) and high HRT values are used for COD removal plus nitrification/denitrification (usually associated with long SRTs, e.g., 30-40 days). Bioreactors employing Kubota flat-sheet microfiltration membranes treating domestic sewage/kitchen wastewater have HRT values within the very narrow range of 7.2-7.92 hours (Kubota Corp., 2002, Trivedi, 2004, Verrecht et al., 2009, Gander et al., 2000).

\section{Mixed liquor suspended solids (MLSS) concentration and solids retention time (SRT)}

The proposed hybrid bioreactor shall have attached and suspended biomass in the CBC, but only suspended biomass in the SMC. Readily biodegradable constituents of the wastewater shall be mainly removed by the attached biomass whilst particulate organic matter shall be mainly removed by the suspended biomass (Leiknes et al., 2007).

The concentration of the attached biomass will be established following the initial experimental tuning phase; being a function of the carriers' type and FR as well as other operating conditions. MLSS 
concentration in the SMC shall be controlled within the range 8-10 $\mathrm{g} / \mathrm{L}$ through wasting an appropriate amount of mixed liquor periodically. The aforementioned MLSS concentration range is optimum due to a number of factors, such as liquor's viscosity affecting oxygen dissolution, membrane TMP and fouling, etc. (Field et al., 1995, Trivedi, 2004, Verrecht et al., 2009). Relatively long SRT values are required for the suspended biomass to facilitate the development of nitrifying bacteria (SRT $\geq 20$ days).

\section{Profile of dissolved oxygen (DO) values in the proposed hybrid bioreactor}

The average DO value in the SMC will be determined by the previously mentioned air diffusion rate for membrane scouring. It is anticipated to be more than $2.0 \mathrm{mg} / \mathrm{L}$, which would ensure the removal of COD as well as nitrification of the wastewater in this compartment considering its HRT (Wang et al., 2006).

Two DO probes shall be placed in the CBC during the initial tuning experimental phase. One probe shall be positioned at the top of the riser to indicate the maximum DO value in this compartment whilst the other probe shall be positioned immediately below the air sparger, also in the riser, to indicate the minimum DO value.

The experimental phase shall have as one of its objectives controlling the upper DO probe indication at a value within the range $1-2 \mathrm{mg} / \mathrm{L}$ since an oversupply

\section{References}

Andersen, R., Chapman, S.J., Artz, R.R.E, 2013. Microbial communities in natural and disturbed peatlands: a review. Soil Biol. Biochem. 57, 979-994. https://doi.org/10.1016/j. soilbio.2012.10.003

Calderon, K., Martin-Pascual, J., Poyatos, J.M., Rodlas, B., Gonzalez-Martinez, A., Gonzalez-Lopez, J., 2012. Comparative analysis of the bacterial diversity in a lab-scale moving bed biofilm reactor applied to treat urban wastewater under different operational conditions. Bioresource Tech. 121, 119126. https://doi.org/10.1016/j.biortech.2012.06.078

Chisti, M.Y., Moo-Young, M., 1988. Gas holdup in pneumatic reactors. Chem. Eng. J. 38, 149-152. https://doi. org/10.1016/0300-9467(88)80073-X of oxygen can lead to poor denitrification in the anoxic zone. Simultaneously, the lower DO probe indication value should be as much below $1.0 \mathrm{mg} / \mathrm{L}$ as practically possible (Leyva-Diaz et al., 2013).

\section{Conclusion}

In this article, the developed conceptual design of a pilot-scale hybrid bioreactor for the treatment of $120 \mathrm{~m}^{3} /$ day of domestic sewage was presented. The bioreactor consists of two compartments: an upstream mainly anoxic CBC and a downstream oxic SMC. The two compartments have the same nominal effective volume of $29 \mathrm{~m}^{3}$ each, making the bioreactor's nominal average HRT 11 hours; 5.5 hours in each compartment.

The CBC is split by a vertical baffle into two equal sections: a riser and a downcomer. Mixed liquor shall be recirculated from the SMC to the top of the downcomer of the CBC to effect the bioreactor's A/O arrangement for denitrification. Part of this recirculated flow shall be sonicated to control the overgrowth of filamentous bacteria.

An experimental tuning phase programme will be carried out following implementation to optimise the functionality of the $\mathrm{CBC}$ with respect to the type and FR of the biomass carriers, the liquid circulation velocity, and the DO profile to maximise denitrification.

Chisti, M.Y., Halard, B., Moo-Young, M., 1988. Liquid circulation in airlift reactors. Chem. Eng. Sci. 43, 451-457. https://doi. org/10.1016/0009-2509(88)87005-2

Chu, L., Wang, J., 2011. Comparison of polyurethane foam and biodegradable polymer as carriers in moving bed biofilm reactor for treating wastewater with a low $\mathrm{C} / \mathrm{N}$ ratio. Chemosphere 83, 63-68. https://doi.org/10.1016/j.chemosphere.2010.12.077

Chu, L., Wang, J., Quan, F., Xing, X-H., Tang, L., Zhang, C., 2014. Modification of polyurethane foam carriers and application in a moving bed biofilm reactor. Process Biochem. 49, 1979-1982.https://doi.org/10.1016/j.procbio.2014.07.018 
Chua, H.C., Arnot, T.C., Howell, J. A., 2004. Controlling fouling in membrane bioreactors operated with a variable throughput. Desalination 160, 67-74.

Colares, G.B., Melo, V.M.M., 2013. Relating microbial community structure and environmental variables in mangrove sediments inside Rhizophora mangle L. habitats. Appl. Soil Ecol. 64, 171-177. https://doi.org/10.1016/j.apsoil.2012.12.004

Cote, P., Buisson, H., Pound, C., Arakaki, G., 1997. Immersed membrane activated sludge for the reuse of municipal wastewater. Desalination 113, 189-196. https://doi.org/10.1016/ S0011-9164(97)00128-8

Di Trapani, D., Di Bella, G., Mannina, G., Torregrossa, M., Viviani, G., 2014. Comparison between moving bed-membrane bioreactor and membrane bioreactor systems: influence of wastewater salinity variation. Bioresource Tech. 162, 60-69. https://doi.org/10.1016/j.biortech.2014.03.126

Duan, L., Song, Y., Xia, S., Hermanowicz, S.W., 2013. Characterization of nitrifying microbial community in a submerged membrane bioreactor at short solids retention times. Bioresource Tech. 149, 200-207. https://doi.org/10.1016/j. biortech.2013.09.050

Field, R.W., Wu, D., Howell, J.A., Gupta, B.B., 1995. Critical flux concept for microfiltration fouling. J. Membr. Sci. 100, 259272. https://doi.org/10.1016/0376-7388(94)00265-Z

Frijters, C.T.M.J., Eikelbloom, D.H., Mulder, A., Mulder, R., 1997. Treatment of municipal wastewater in a CircoxR airlift reactor with integrated denitrification. Water Sci. Tech. 36, 173-181.

Gander, M., Jefferson, B., Judd, S., 2000. Aerobic MBRs for domestic wastewater treatment: a review with cost considerations. Sep. Purif. Tech. 18, 119-130. https://doi.org/10.1016/ S1383-5866(99)00056-8

Garrido, J.M., van Benthum, W.A.J., van Loosdrecht, M.C.M., Heijnen, J.J., 1997. Influence of dissolved oxygen concentration on nitrite accumulation in a biofilm airlift suspension reactor. Biotechnol. Bioeng. 53, 168-178. https://doi.org/10.1002/ (SICl)1097-0290(19970120)53:2<168::AID-BIT6>3.0.C0;2-M

Hasar, H., Kinaci, C., Unlu, A., Togrul, H. Ipek, U., 2000. Rheological properties of activated sludge in sMBR. Biochem. Eng. J. 20, 1-6. https://doi.org/10.1016/j.bej.2004.02.011

Heijnen, J.J., van't Riet, K, 1984. Mass transfer, mixing and heat transfer phenomena in low viscosity bubble column reactors. Chem. Eng. J. 28, B21. https://doi.org/10.1016/03009467(84)85025-X

Heijnen, J.J., Hols, J., van der Lans, R.G.J.M., van Leeuwen, H.L.J.M., Mulder, A., Weltevrede, R., 1997. A simple hydrodynamic model for the liquid circulation velocity in a full-scale two- and three-phase internal airlift reactor operating in the gas recirculation regime. Chem. Eng. Sci. 52, 2527-2540. https://doi.org/10.1016/S0009-2509(97)00070-5

Hocaoglu, S.M., Insel, G., Cokgor, E.U., Orhon, D., 2011. Effect of low dissolved oxygen on simultaneous nitrification and denitrification in a membrane bioreactor treating black Water. Bioresource Tech. 102, 4333-4340. https://doi.org/10.1016/j. biortech.2010.11.096

Hwang, S.J., Cheng, Y-L., 1997. Gas holdup and liquid velocity in three-phase internal-loop airlift reactors. Chem. Eng. Sci. 52, 3949-3960. https://doi.org/10.1016/S00092509(97)88931-2

Karamanev, D.G., Nagamune, T., Endo, I., 1992. Hydrodynamics and mass transfer study of a gas-liquid-solid draft tube spouted bed bioreactor. Chem. Eng. Sci. 47, 3581-3588. https://doi.org/10.1016/0009-2509(92)85073-K

Kubota Corp., 2002. Kitchen Wastewater Reuse System using KUBOTA Submerged Membrane Unit in KUBOTA Hanshin Office, Japan.

Kubota Corp: How to design Kubota submerged membrane process, Manual, Kubota. Japan.

Lazarova, V., Meyniel, J., Duval, L., Manem, J., 1997. A novel circulating bed bioreactor: hydrodynamics, mass transfer and nitrification capacity. Chem. Eng. Sci. 52, 3919-3927. https:// doi.org/10.1016/S0009-2509(97)00288-1

Lee, W-N., Kang, I-J., Lee, C-H., 2006. Factors affecting filtration characteristics in membrane-coupled moving bed biofilm reactor. Water Res. 40, 1827-1835. https://doi.org/10.1016/j. watres.2006.03.007

Leiknes, T., Bolt, H., Engmann, M., Ødegaard, H., 2006. Assessment of membrane reactor design in the performance of a hybrid biofilm membrane bioreactor. Desalination 199, 328330. https://doi.org/10.1016/j.desal.2006.03.181

Leiknes, T., Ødegaard, H., 2007. The development of a biofilm membrane bioreactor. Desalination 202, 135-143. https://doi. org/10.1016/j.desal.2005.12.049

Leyva-Diaz, J.C., Calderon, K., Rodriguez, F.A., Gonzalez-Lopez, J., Hontoria, E., Poyatos, J.M., 2013. Comparative kinetic study between moving bed biofilm reactor-membrane bioreactor and membrane bioreactor systems and their influence on organic matter and nutrients removal. Biochem. Eng. J. 77, 28-40. https://doi.org/10.1016/j.bej.2013.04.023

Lu, W. J., Hwang, S-J., Chang, C-M., 1995. Liquid velocity and gas holdup in three-phase internal loop airlift reactors with low-density particles. Chem. Eng. Sci. 50, 1301-1310. https:// doi.org/10.1016/0009-2509(95)98842-3 
Miyahara, T., Kawate, O., 1993. Hydrodynamics of a solid-suspended bubble column with a draught tube containing low-density particles. Chem. Eng. Sci. 48, 127-133. https:// doi.org/10.1016/0009-2509(93)80289-3

Neis, U., Banduch, T., Nickel, K., 2012. Stimulation of aerobic and anaerobic biological processes by ultrasound. E-Water, European Water Association.

Nogueira, R., Lazarova, V., Manem, J., Melo, L.F., 1998. Influence of dissolved oxygen on the nitrification kinetics in a circulating bed biofilm reactor. Bioprocess Eng. 19, 441 - 449. https://doi.org/10.1007/s004490050546

Pal, L., Kraigher, B., Brajer-Humar, B., Levstek, M., Mandic-Mulsc, I., 2012. Total bacterial and ammonia-oxidizer community structure in moving bed biofilm reactors treating municipal wastewater and inorganic synthetic wastewater. Bioresource Tech. 110, 135-143. https://doi.org/10.1016/j.biortech.2012.01.130

Picioreanu, C., van Loosdrecht, M.C.M., Heijnen, J.J., 1996. Modelling the effect of oxygen concentration on nitrite accumulation in a biofilm airlift suspension reactor, IAWQ Special Conference on Biofilm Systems. Copenhagen, Denmark.

Quan, F., Yuxiao, W., Tiannin, W., Hao, Z., Libing, C., Chong, Z., Hongzhang, C., Xiuqin, K., Xin-Hui, X., 2012. Effect of packing rates of cubic-shaped polyurethane foam carriers on the microbial community and the removal of organics and nitrogen in moving bed biofilm reactors. Bioresource Tech. 117, $201-$ 207. https://doi.org/10.1016/j.biortech.2012.04.076

Rusten, B., Eikebrokk, B., Ulgenes, Y., Lygren, E., 2006. Design and operation of the Kaldnes moving bed biofilm reactors. Aquacultural Eng. 34, 322-331. https://doi.org/10.1016/j. aquaeng.2005.04.002

Sofia, A., Ng, W.J., Ong, S.L., 2004. Engineering design approaches for minimum fouling in submerged MBR. Desalination 160, 67-74. https://doi.org/10.1016/S00119164(04)90018-5

Tang, B., Qiu, B., Huang, S., Yang, K., Bin, L., Fu, F., Yang, H., 2015. Distribution and mass transfer of dissolved oxygen in a multi-habitat membrane bioreactor. Bioresource Tech. 182, 323-328. https://doi.org/10.1016/j.biortech.2015.02.028

Tchobanoglous, G., Burton, F.L., David Stensel H., 2003. Wastewater Engineering Treatment and Reuse (Metcalf and Eddy Inc.), 4th ed., McGraw-Hill, N.Y. pp. 854-859.

Trivedi, H.K., 2004. Flat-plate microfiltration membrane bioreactor designed for ultimate nutrient removal. WEFTEC Water Environment Federation, Austin, Texas, USA.

Trussell, R.S., Adham, S., Trussell, R.R., 2005. Process limits of municipal wastewate treatment with the submerged membrane bioreactor. J. Env. Eng. 131, 410-416. https://doi. org/10.1061/(ASCE)0733-9372(2005)131:3(410)

Trussell, R.S., Merlo, R.P., Chang, S., Jolis, D., Sukapanpotharam, P., Bucher, B., Hermanowicz, S.W., Jenkins, D., 2006. Treating wet weather flow in a membrane bioreactor: Changes in mixed liquor properties cannot be neglected, WEFTEC Water Environment Foundation. Pasadena, CA, USA.

Van der Lans, R., 1985. Hydrodynamics of a bubble column loop reactor. Ph.D. thesis, Delft University of Technology, The Netherlands.

Verrecht, B., Gugliemi, G., Mulder, J.W., Brepols, C., Judd, S., 2009. An aeration energy model for an immersed membrane bioreactor. MBR-Network (EU) Final Workshop, Berlin, Germany.

Wang, X.J., Xia, S.Q., Chen, L., Zhao, J.F., Renault, N.J., Chovelon, J.M., 2006. Nutrients removal from municipal wastewater by chemical precipitation in a moving bed biofilm reactor. Process Biochem. 41, 824-828. https://doi.org/10.1016/j. procbio.2005.10.015

Yang, Q., Chen, J., Zhang, F., 2006. Membrane fouling control in a submerged membrane bioreactor with porous, flexible suspended carriers. Desalination 189, 292-302. https://doi. org/10.1016/j.desal.2005.07.011

Yang, S., Yang, F., Fu, Z., Lei, R., 2009. Comparison between a moving bed membrane bioreactor and a conventional membrane bioreactor on organic carbon and nitrogen removal. Bioresource Tech. 100, 2369-2374. https://doi.org/10.1016/j. biortech.2008.11.022

Yoon, S-H., Kim, H-S., Yeom, I-T., 2004. The optimum operational condition of membrane bio-reactor: cost estimation of aeration and sludge treatment. Water Res. 38, 37-46. https:// doi.org/10.1016/j.watres.2003.09.001

Zhang, S., Wang, Y., He, W., Xing, M., Wu, M., Yang, J., Gao, N., Sheng, G., Yin, D., Liu, S., 2013. Linking nitrifying biofilm characteristics and nitrification performance in moving-bed biofilm reactors for polluted raw water pretreatment. Bioresource Tech. 146, 416-425. https://doi.org/10.1016/j.biortech.2013.07.056

Zhang, S., Wang, Y., He, W., Wu, M., Xing, M., Yang, J., Gao, N., Pan, M., 2014. Impact of temperature and nitrifying community on nitrification kinetics in a moving-bed biofilm reactor treating polluted raw water. Chem. Eng. J. 236, 242-250. https://doi.org/10.1016/j.cej.2013.09.086

Zhu, Y., Zhang, Y., Ren, H-q., Geng, J-j., Xu, K., Huang, H., Ding, L-l., 2015. Physicochemical characteristics and microbial community evolution of biofilms during the start-up period in a moving bed biofilm reactor. Bioresource Tech. 180, 345-351. https://doi.org/10.1016/j.biortech.2015.01.006 


\section{Pilotinio cirkuliacinio membraninio bioreaktoriaus, skirto srutų valymui, modelio kūrimas}

Gauta:

2017 m. gegužè

Priimta spaudai: 2017 m. liepa

\section{Abdul-Fattah Mohamed Ali, Zainab Ziad Ismail}

Bagdado universitetas, Aplinkos inžinerijos katedra, Bagdadas, Irakas

Populiacijos didejimas besivystančiose šalyse veda prie esamu nuoteku valymo įrenginiu perkrovos. Be to, priemiestiniai gyvenamieji rajonai dè jvairiu priežasčiu kartais yra pastatomi ir apgyvendinami anskčiau nei įrengiami nuoteku valymo įrenginiai. Dèl šios priežasties yra poreikis vietiniams, moduliniams ¡̇renginiams, kurie būtų tvirti ir reikalautų minimalios priežiūros. Šiame tyrime yra nagrinejjamas įrenginio, skirto išvalyti $120 \mathrm{~m}^{3}$ nuotekų per dieną, hibridinio bioreaktoriaus koncepcinis modelis. Siūlomas bioreaktorius susideda iš priešsrovinio cirkuliacinio sluoksnio kameros (CSK) su plastikiniais bioplèvelès nešejais ir iš pasroviui tekančios mikrofiltracijos membranos kameros (MMK). Kiekvienas iš šiu dvieju kameru turi $29 \mathrm{~m}^{3}$ nominalu tūri. Cirkuliacinio sluoksnio kamera daugiausiai yra anoksiška, kai tuo tarpu mikrofiltracijos membranos kamera yra aerobinè (oksiška), sukurianti reaktoriuje A/O sąlygas. Diegiant pilotini ¡rengini, numatoma pradine eksperimentinè fazè, skirta reaktoriui sureguliuoti, atsižvelgiant i funkcionalumą ir maksimalų azoto šalinimą. Šio derinimo etapo detales taip pat yra aprašomos šiame straipsnyje.

Raktiniai žodžiai: srutų valymas, hibridinis bioreaktorius, cirkuliacinis sluoksnis, panardinta membrana, biomasès nešejai. 